\title{
METODE PEMBELAJARAN KONTEKSTUAL SEBAGAI UPAYA PENINGKATAN MOTIVASI BELAJAR AKUNTANSI MAHASISWA UNIVERSITAS DHARMAWANGSA
}

\author{
Lukman Hakim Siregar, Listya Devi Junaidi, \& Diyah Atika \\ Jurusan Akuntansi, Fakultas Ekonomi, Universitas Dharmawangsa Medan, Indonesia \\ e-mail:lukmanhakim@dharmawangsa.ac.id
}

\begin{abstract}
Based on midterm exam results there are still many students who get grades below the graduation average. As for several factors that cause, among others: students are very difficult to understand the concept of accounting, lack of motivation for students to study accounting and students are more passive and less able to work together in groups. This study uses class action methods and quantitative research methods, namely using multiple linear regression analysis. The location of the study was conducted at the University of Dharmawangsa Medan. The data source of this research is using primary data and secondary data. The stages of this research process are class action, data quality test, classic assumption test, and hypothesis test. The results of this study that in the application of contextual learning have not been fully carried out by accounting lecturers because they have not fully understood how the contextual learning method is. Simultaneously, contextual learning methods have a significant effect on motivation, but contextual learning methods do not affect student learning outcomes.
\end{abstract}

Keywords: contextual, motivation, learning outcomes

\section{PENDAHULUAN}

Memahami ilmu akuntansi tidaklah mudah, adanya beberapa tahapan dan prosedur yang harus dipahami membuat ilmu akuntansi terlihat sulit yaitu mulai dari persamaan akuntansi hingga laporan keuangan. Untuk memahami setiap tahapan dan prosedur tersebut, cukup banyak mahasiswa yang mengalami kendala dan kesulitan dalam mempelajarinya yang dapat disebabkan oleh beberapa faktor tertentu. Pada dasarnya, setiap mahasiswa memiliki tingkat pemahaman yang berbeda-beda. Oleh karena itu, diperlukan metode pembelajaran yang berbeda untuk mempermudah mahasiswa dalam memahami ilmu akuntansi dan dapat meningkatkan motivasi belajar mahasiswa.

Dosen merupakan pihak yang berperan penting dalam membangun motivasi dan memberikan pembelajaran kepada mahasiswa. Diharapkan dosen dapat memahami tingkat pemahaman masing-masing mahasiswanya sehingga dapat mengoptimalkan metode pembelajaran yang sesuai. Adapun masalah yang sedang dihadapi yaitu bagaimana kemampuan dan kompetensi dosen itu sendiri dari segi kecakapan mengajar (ketepatan pemilihan metode pendekatan belajar, evaluasi dan improvisasi). Sampai saat ini masih banyak anggapan bahwa akuntansi itu sulit untuk di pelajari sehingga memengaruhi motivasi belajar mahasiswa.

Pada dasarnya, motivasi tidak sama dengan motif, walaupun memiliki kata dasar yang sama yaitu modicum. Secara psikologis, motivasi atau motivation berarti suatu hal yang timbul untuk bersemangat dan bergairah dalam mencapai tujuan tertentu. Dalam konsep pembelajaran, motivasi berarti suatu seni untuk mendorong mahasiswa dalam melakukan kegiatan belajar 
demi tercapainya tujuan pembelajaran. Oleh karena itu, motivasi merupakan usaha dari dosen untuk membantu mahasiswanya dalam mendukung dan mendorong mahasiswa demi tercapainya tujuan pembelajaran.

Metode pembelajaran kontekstual atau disebut CTL (contextual teaching and learning) merupakan proses pembelajaran dengan menggunakan metode pembelajaran yang berbeda dari biasanya. Hal ini dikarenakan dalam metode CTL, mahasiswa dilibatkan dalam pemahaman materi pelajaran yang sedang dipelajarinya yaitu dengan menyandingkan materi tersebut dengan konteks kehidupan yang sebenarnya mulai dari kegiatan pribadi, sosial, dan kultural sehingga mahasiswa memiliki pemahaman yang cukup luas di mana materi tersebut dapat diterapkan secara langsung ke dalam kehidupan sehari-hari mereka. Sebagai contoh, dalam transaksi jual beli dosen bisa mengajarkan mahasiswa bagaimana cara membuat pencatatan jurnal umum dengan mengilustrasikan pada saat mahasiswa membeli barang atau makanan saat di kantin. Dengan cara tersebut, mahasiswa bisa membayangkan langsung dan mempraktikkan langsung materi yang sudah dia pelajari.

CTL adalah metode pembelajaran di mana dosen memberikan ilustrasi kehidupan sehari-hari ke dalam kelas dan mendorong mahasiswa dapat memahami dan menerapkan pengetahuan yang dimilikinya dalam kehidupan sehari-hari sebagai masyarakat dan keluarga. Dengan adanya metode CTL ini, diharapkan lebih bermakna bagi mahasiswa dan memiliki motivasi dan kesan tersendiri bagi mereka bukan hanya sekadar mentransfer ilmu dan pengetahuan dari dosen ke mahasiswa saja. Metode dengan pendekatan konstruktif dipandang sebagai salah satu strategi yang memenuhi prinsip-prinsip pembelajaran berbasis kompetensi. Adanya lima strategi pembelajaran CTL, yaitu relating, experiencing, applying, cooperat- ing, dan transferring diharapkan mahasiswa mampu mencapai kompetensi secara maksimal.

\section{METODE PENELITIAN}

Metode yang digunakan dalam penelitian ini adalah penelitian tindakan kelas dan metode penelitian kuantitatif. Adapun metode tindakan kelas ini memiliki empat tahap yaitu perencanaan, pelaksanaan tindakan, pengamatan, dan refleksi. Keempat tahap tersebut membentuk suatu siklus yang hanya dilakukan sekali saja karena keterbatasan waktu.

Selanjutnya, peneliti menggunakan metode penelitian kuantitatif untuk mengetahui dan menganalisis permasalahan yang ada dalam penelitian ini. Berikut adalah gambar kerangka konseptual penelitian.

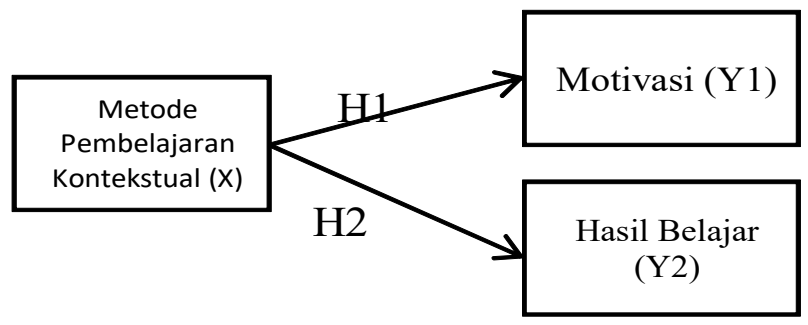

\section{Gambar 1.1 Kerangka Konsep}

Berdasarkan gambar tersebut, hipotesis yang gunakan adalah sebagai berikut.

H1: Metode pembelajaran kontekstual berpengaruh terhadap motivasi belajar mahasiswa.

H2: Metode pembelajaran kontekstual berpengaruh terhadap hasil belajar mahasiswa.

Pada penelitian kuantitatif, proses pengolahan data menggunakan program SPSS 23. Adapun tahap penelitian kuantitatif penelitian ini sebelumnya melakukan uji validitas dan uji reliabilitas, selanjutnya peneliti melakukan pengujian asumsi klasik yaitu uji normalitas, uji multikolinieritas, dan uji heterokedastisitas. 
Pada pengujian hipotesis, peneliti menggunakan analisis regresi linier dengan persamaan berikut.

$$
\begin{aligned}
& \mathrm{Y} 1=\beta 0+\beta 1 X 1+\varepsilon \\
& \mathrm{Y} 2=\beta 0+\beta 1 X 1+\varepsilon
\end{aligned}
$$

Di mana:

X1: model pembelajaran CTL

Y1 : motivasi belajar mahasiswa

Y2 : hasil belajar mahasiswa

$\beta 0$ : konstanta

$\beta 1$ : koefisien

$\varepsilon$ : error term

\section{HASIL DAN PEMBAHASAN}

Berdasarkan hasil penelitian tindakan kelas nilai yang di peroleh pra-intervensi menunjukkan bahwa dari 53 mahasiswa terdapat 11 mahasiswa yang belum mencapai nilai KKM yaitu 65 pada mata kuliah teori akuntansi. Bila dipersentasekan sebesar 20,75\% yang dikategorikan belum mampu mencapai indikator KKM teori akuntansi. Namun, hasil yang diperoleh setelah melalui siklus I menunjukkan bahwa dari 53 mahasiswa hanya 3 mahasiswa yang tidak mencapai kriteria KKM (65) pada mata kuliah teori akuntansi. Peneliti menyimpulkan bahwa tindakan kegiatan sudah lebih baik dan hasilnya juga sudah sesuai target keinginan peneliti yaitu 94,33\% mahasiswa telah mencapai KKM teori akuntansi. Dengan demikian, penelitian dianggap telah berhasil dengan tujuan penelitian.

Berdasarkan hasil pengujian hipotesis, hasil uji simultan (F) adalah sebagai berikut.

\begin{tabular}{|c|c|c|c|c|c|c|}
\hline \multicolumn{7}{|c|}{ ANOVA $^{a}$} \\
\hline & & $\begin{array}{l}\text { Sum of } \\
\text { Squares }\end{array}$ & df & Mean Square & $\mathrm{F}$ & Sig. \\
\hline \multirow[t]{3}{*}{1} & Regression & 625,129 & 1 & 625,129 & 69,765 & $.000^{b}$ \\
\hline & Residual & 456,984 & 51 & 8.960 & & \\
\hline & Total & 1082,113 & 52 & & & \\
\hline
\end{tabular}

Tabel 1.1 Hasil Uji f X terhadap Y1

a. Dependent Variable: Motivasi

b. Predictors: (Constant), Kontekstual

Sumber: data diolah, 2020
Tabel 1.2 Hasil Uji f X terhadap Y2

\begin{tabular}{|c|c|c|c|c|c|c|}
\hline Mo & & $\begin{array}{l}\text { Sum of } \\
\text { Squares }\end{array}$ & df & Mean Square & $\mathrm{F}$ & Sig. \\
\hline \multirow[t]{3}{*}{1} & Regression & 127,248 & 1 & 127,248 & \multirow[t]{3}{*}{.860} & \multirow[t]{3}{*}{$358^{\mathrm{b}}$} \\
\hline & Residual & 7547,266 & 51 & 147,986 & & \\
\hline & Total & 7674,513 & 52 & & & \\
\hline
\end{tabular}

ANOVA $^{\text {a }}$

Sumber: data diolah, 2020

Berdasarkan hasil uji simultan (Uji F) pada Tabel 1.1 maka diperoleh nilai $\mathrm{F}_{\text {hitung }}$ sebesar 69,795 dengan tingkat signifikansi 0,000. Sementara nilai $\mathrm{F}_{\text {tabel }}$ adalah 4,03. Oleh karena $\mathrm{F}_{\text {hitung }}>$ $\mathrm{F}_{\text {tabel }}(69,795>4,03)$ dan tingkat signifikansi lebih kecil dari 0,05 $(0,000<0,05)$, maka H1 diterima. Dengan demikian, dapat disimpulkan bahwa variabel independen metode pembelajaran kontekstual secara simultan atau bersama-sama berpengaruh signifikan terhadap motivasi.

Berdasarkan hasil uji simultan (Uji F) pada Tabel 1.2 maka diperoleh nilai $\mathrm{F}_{\text {hitung }}$ sebesar 0,890 dengan tingkat signifikansi 0,358 . Sementara nilai $\mathrm{F}_{\text {tabel }}$ adalah 4,03. Oleh karena $\mathrm{F}_{\text {hitung }}<$ $\mathrm{F}_{\text {tabel }}(0,890<4,03)$ dan tingkat signifikansi lebih besar dari 0,05 (0,358 > 0,05), maka Ho diterima. Dengan demikian, dapat disimpulkan bahwa variabel independen metode pembelajaran kontekstual secara simultan atau bersama-sama tidak berpengaruh signifikan terhadap hasil belajar.

Jika dilihat dari uji simultan, yang memiliki pengaruh hanyalah variabel metode pembelajaran kontekstual terhadap motivasi belajar maka dapat dihitung seberapa besar nilai pengaruhnya melalui uji R Square sebagai berikut.

Tabel 1.3 Hasil Uji R-Square

\begin{tabular}{|l|c|r|r|r|}
\multicolumn{7}{c|}{ Model Summary } \\
\hline Model & R & R Square & $\begin{array}{c}\text { Adjusted R } \\
\text { Square }\end{array}$ & $\begin{array}{c}\text { Std. Error of } \\
\text { the Estimate }\end{array}$ \\
\hline 1 &, $760^{\text {a }}$ &, 578 &, 569 & 2,99340 \\
\hline
\end{tabular}

a. Predictors: (Constant), Kontekstual

Sumber: data diolah, 2020 
Hasil uji koefisien determinasi pada Tabel 1.3 menunjukkan nilai $\mathrm{R}$ sebesar 0,760 yang berarti korelasi atau hubungan antara variabel dependen dengan variabel-variabel independen yang kuat karena lebih besar dari 0,5 (50\%). Sementara nilai Adjusted $R$ Square adalah 0,569. Angka ini mengindikasikan bahwa sebesar 56,9\% motivasi belajar mahasiswa dapat dijelaskan variabel metode pembelajaran kontekstual. Sementara sisanya sebesar $43,1 \%$ dijelaskan oleh variabel-variabel lain yang tidak dimasukkan dalam model penelitian.

\section{PEMBAHASAN}

Penerapan pembelajaran kontekstual belum dilakukan sepenuhnya oleh dosen-dosen Akuntansi berdasarkan hasil observasi yang dilakukan oleh peneliti. Dalam hal ini dosen-dosen masih senantiasa dengan melakukan metode ceramah, bahkan masih ada yang mencatat salinan berdasarkan buku yang menjadi referensi dalam perkuliahan. Mahasiswa mengungkapkannya kepada penulis dalam hal wawancara pada penelitian ini. Hal ini jelas tidak menarik dan menumbuhkan motivasi belajar mahasiswa Dharmawangsa jurusan akuntansi sehingga mahasiswa juga merasakan kejenuhan dalam pembelajaran.

Berdasarkan penelitian yang telah dilakukan oleh penulis, yakni dengan tindakan kelas dan juga penelitian kuantitatif berdasarkan pengolahan hasil nilai belajar mahasiswa dapat kita lihat bahwa metode pembelajaran kontekstual mempunyai dampak yang positif terhadap motivasi belajar mahasiswa dan keinginan belajar mahasiswa meningkat dikarenakan setiap mahasiswa mempunyai peran masing-masing dalam menyelesaikan masalahnya berdasarkan bidang ilmu yang sedang diembannya.
Metode pembelajaran kontekstual yang dilakukan oleh penulis memang berpengaruh signifikan terhadap motivasi belajar mahasiswa, namun tidak berdampak ataupun berpengaruh pada hasil belajar mahasiswa yang telah tergambar pada hasil analisis yang dibuat oleh penulis. Pembelajaran kontekstual yang dilakukan oleh penulis hanya berdasarkan momentum penelitian yang dilakukan dan tidak dilakukan secara terusmenerus. Hal ini belum memberikan pengaruh pada nilai hasil belajar mahasiswa Universitas Dharmawangsa Jurusan Akuntansi.

\section{SIMPULAN}

1. Penerapan pembelajaran kontekstual belum dilakukan sepenuhnya oleh dosen-dosen akuntansi dikarenakan belum memahaminya secara keseluruhan bagaimana metode pembelajaran kontekstual tersebut.

2. Metode pembelajaran kontekstual mampu meningkatkan motivasi belajar mahasiswa. Hal ini terlihat dari hasil tindakan kelas dan hasil analisis regresi yang menunjukkan $\mathrm{F}_{\text {hitung }}$ $>\mathrm{F}_{\text {tabel }}(69,795>4,03)$ dan tingkat signifikansi lebih kecil dari 0,05 $(0,000<0,05)$. Oleh karena itu, secara simultan metode pembelajaran kontekstual berpengaruh terhadap motivasi belajar mahasiswa.

3. Metode pembelajaran kontekstual berpengaruh terhadap motivasi belajar mahasiswa yang ditunjukkan dengan nilai uji simultan $\mathrm{F}_{\text {hitung }}>$ $\mathrm{F}_{\text {tabel }}(69,795>4,03)$ dan tingkat signifikansi lebih kecil dari $0,05(0,000<0,05)$, dan nilai $\mathrm{R}^{2}$ sebesar $56,9 \%$. Namun, metode pembelajaran kontekstual tidak berpengaruh terhadap hasil belajar mahasiswa yang ditunjukkan dengan hasil uji simultan $\mathrm{F}_{\text {hitung }}<\mathrm{F}_{\text {tabel }}(0,890<$ $4,03)$ dan tingkat signifikansi lebih besar dari $0,05(0,358>0,05)$. 


\section{DAFTAR PUSTAKA}

Abdurrahman, Mulyono. 2003. Pendidikan bagi Anak Berkesulitan Belajar. Jakarta: Rineka Cipta.

Arikunto, Suharsimi, dkk. 2011. Penelitian Tindakan Kelas. Jakarta: PT Bumi Askara.

Hamalik, Oemar. 2008. Proses Belajar Mengajar. Jakarta: Bumi Aksara.

Nurhadi. 2002. Pendekatan Kontekstual. (Contextual Teaching and Learning CTL)). Departemen Pendidikan Nasional.
Rasyad, Aminuddin. 2006. Teori Belajar dan Pembelajaran. Jakarta: PT Uhamka Press.

Sagala, Syaiful H. 2006. Konsep dan Makna Pembelajaran. Bandung: Alfabeta.

Sukmadinata, Nana Syaodih. 2005. Metode Penelitian. Bandung: Remaja Rosdakarya.

Syaiful Bahri Djamarah dan Aswan Zain.2010. Strategi Belajar Mengajar. Jakarta: Rineka Cipta. 
Accounting and Management Journal, Vol. 4, No. 2, December 2020 